\title{
Medicine \& Science in Sports \& Exercise
}

Issue: Volume 42(5) Supplement 1, May 2010, pp 776-777

Copyright: (C)2010The American College of Sports Medicine

Publication Type: [F-34 Free Communication/Poster - Protein/Amino Acid

Supplementation: JUNE 4, 2010 1:00 PM - 6:00 PM: ROOM: Hall C]

DOI: $10.1249 / 01 . M S S .0000386251 .15020 . d 2$

ISSN: 0195-9131

Accession: 00005768-201005001-02271

[F-34 Free Communication/Poster - Protein/Amino Acid Supplementation: JUNE 4, 2010 1:00 PM - 6:00 PM: ROOM: Hall C]

\section{The Effects Of Prior Exercise And Protein Co-ingestion On The Glycemic Response To Carbohydrate.: 2863: Board \#214 June 4 3:30 PM - 5:00 PM}

Leveritt, Michael; Roberts, Shelley; Grant, Gary; Dukie, Shailendra; Desbrow, Ben

\section{Author Information}

Griffith University, Gold Coast, Queensland, Australia. (Sponsor: Louise Burke, FACSM)

Email:m.leveritt@griffith.edu.au

PURPOSE: The purpose of this study was to investigate the effects of prior exercise and protein co-ingestion on the glycemic response to the ingestion of carbohydrate.

METHODS: 21 healthy subjects ( 13 men and 8 women; $22+/-3.82$ yrs $174+/-6.7 \mathrm{~cm}$, body weight $69+/-11.5 \mathrm{~kg}$; values are mean+/-SD) participated in 4 trials in random order after an overnight fast. These included: 1) glucose ingestion at rest (RG), 2) glucose and protein ingestion at rest (RGP), 3) glucose ingestion after exercise (EG), and 4) glucose and protein ingestion after exercise (EGP). Exercise consisted of 45 minutes of cycling at $60 \%$ of subjects' age-predicted maximum heart rate. Test drinks contained $50 \mathrm{~g}$ glucose or $50 \mathrm{~g}$ glucose with $20 \mathrm{~g}$ whey protein. Venous blood samples were taken $0,15,30,45,60,75,90,105$ and 120 minutes after drink consumption. Blood plasma was subsequently analysed for glucose and insulin.

RESULTS: Plasma glucose concentration was significantly lower in RGP compared to RG at 30, 45, 60 and 75 minutes and in EGP compared to EG at 30, 45 and 60 minutes ( $p$

CONCLUSION: Co-ingestion of protein with carbohydrate reduces the glycemic response and increases insulinemic response in healthy subjects, while prior low-moderate intensity exercise appears to have minimal effect. 